\title{
CONCEPT AND PECULIARITIES OF ECOLOGICAL NETWORK OF UKRAINE. DOCTRINAL-LEGALLY APPROACHES TO ITS UNDERSTANDING
}

\author{
T. M. KONDRATIUK, assistant \\ of Department of Agricultural, Land and Environmental Law \\ named after Academician V.Z. Yanchuk, \\ National University of Life and Environmental Sciences of Ukraine \\ E-mail: Lawyert@ukr.net
}

Summary. The analysis of scientific approaches to definition of a concept of "ecological network» and its peculiarities is carried out. The attempt to define ecological network as subject to ecology-land legal regulation is made.

Keywords: ecological network, subject to legal regulation, land-law category, nature preservation

\section{Introduction.}

The national ecological network is an ecological component of sustainable development, a basis of preservation of the surrounding environment. On the basis of creation ecological network, the idea of integrity of the nature, coherence and continuity of itsparts of systems of all levels is done. Formations of ecological network are assumed by association in uniform territorial system the persons have poured over valuable lands in ecological, scientific, historical and cultural value and anthropogenically broken lands. Development of national ecological network continues the second decade and especially in recent years having appeared some representatives of legal science pay a lot of attention to questions of its formation and functioning, discussions are done about approach to definition of a concept «econetwork» and its understanding.

\section{Analysis of recent researches and publications.}

V.I. Andreytsev, A.Sh. Chomakhashvili, B. V. Danylenko, A.P. Hetman, A.Y. Hodovaniuk, I.I. Karakash, P.F. Kulynych, O.V. Lozo, M.I. Maksymenko, N.R. Malysheva, V.V. Nosik, Yu.S. Shemshuchenko, O.O. Stativka, M.Ya. Vashchyshyn, etc. worked on questions of formation, functioning and preservation of national ecological network. However, the researchers of the ecological and land law it is insufficiently given attention to land aspect.

Purpose is the analysis of the special legislation regulating questions of creation, functioning and preservation of national econetwork, doctrinal approaches to its definition, and its justification as subject to ecology-land legal regulation.

\section{Results.}

For the first time legislative definition of econetwork in Ukraine is formulated 
in the Law of Ukraine «About the nation program of formation of national ecological network of Ukraine for 2000-2015» and is defined as the uniform territorial system which includes sites of natural landscapes, of subjects to special protection, both territories and objects of natural and reserved background, resort and medical and improving, recreational, water protective, field-protecting territories and objects of its types determined by the legislation of Ukraine and they are the parts of structural territorial elements (further - elements) econetwork natural regions, natural corridors, buffer zones (paragraph 4 subparagraph 1 subsection 1 ) [1].

This definition places emphasis on the list of territories of which the econetwork consists and its structural elements are formed. It is separately divided: a) especially protected natural landscapes and b) territories and objects of natural and reserved background, resort and medical and improving, recreational, water protective, field-protecting territories. However, at the existing nature protection legislation of the territory of a natural and reserved background, etc. make natural landscapes, especially protected.

The adopted Law of Ukraine «About econetwork of Ukraine» [2] econetwork are defined as uniform territorial system which is formed for the purpose of improvement of conditions for formation and restoration of the environment, increase in natural and resource capacity of the territory of Ukraine, preservation landscape and biodiversity, residences and growth of valuable species of an animal and flora, genetic fund, ways of migration of animals by association of territories and objects of natural and reserved background and also other territories having special value for the protection surrounding with in the environment and according to laws and international obligations of Ukraine are subject to special protection. This definition is wider according to contents, the emphasis on the purpose of its creation and functional purpose is placed but all territories which are its components aren't listed, and provides formation of econetwork through a combination of territories of traditional preservation «territories and objects of a natural and reserved background» and also «its territories», uniting their value «having special value for protection of the surrounding environment» and establishes a condition «and according to laws and the international obligations of Ukraine of subjects to special protection». The absence in a concept of the list of territories is appropriate as exempts definition from accumulation. Besides, in paragraph 6 subparagraph4 subsection 1 of the State program and Art. 5 Law of Ukraine «About econetwork of Ukraine» are provided detailed lists of its components, which are slightly not identical.

In turn the All-European strategy [3] which is a fundamental principle of development of All-European econetwork doesn't provide its accurate definition. From its contents it follows that the All-European econetwork is physical network through which measures on preservation of ecosystems, habitats, types, landscapes and its natural resources of the European value and the coordination mechanism by means of which partners in Strategy will be able to develop and carry out joint actions will be taken (paragraph 13 subparagraph 2.5 subsection 2).

In recent years, even more often «econetwork» draws attention of scientific different fields of knowledge. It demonstrates about its interindustry character.

Scientists-jurists and ecologists unambiguously define econetwork first of 
all as the phenomenon, process, tool, object, means of preservation of the nature.

So, on a thought of the naturalist Ya.I. Molchan econetwork is the embodiment of ecosystem approach in the course of, first of all, spatial and planning activity, and it is basic institute of ecologically balanced development at the landscape and ecosystem level [4, p. 43].

The active nature defender erudite naturalist A.A. Kahalo analyzing the principles of formation of econetwork, notes that the econetwork is functionally joint system of nature protection territories of the different status and the auxiliary territories providing biotic functional communication between a biota of different regions and also preservation of conditions for natural (or brought closer to natural) courses of processes of functioning and development of biosystems of different level of the organization. [5, p. 28].

According to I.I. Karakash, econetwork as an object of the ecological right represents a certain complex of natural objects and their resources but integrated at the wide specific level and the widespread territory of Ukraine [6, p. 95].

A.V. Lozo defines ecological network as the comprehensive natural and legal phenomenon which can help Ukraine to keep a valuable natural genepool, to use new effective control levers in management of environmental protection, will promote further ecological cooperation with the European Union and also to solve some problem aspects of legal regulation of landscapes [7, p. 94].

Ye.A. Platonova under econetwork understands uniform territorial structure of sites reserved and a little excited the nature, providing maintaining landscape and biological diversity, create prerequisites for rational environmental management and ecological improve- ment of the territory [8, p. 175]. However, the econetwork unites not only sites reserved and a little excited the nature, subjects to special protection, but also other economic developed territories which provide its integrity.

Besides, in doctrinal sources of the legal direction a concept "econetwork" is considered as subject to legal regulation. The reasonable explanation for such approach was provided by M.Ya. Vashchyshyn. With reference to the doctrine about the theory of the right, it notices that the econetwork is subject to legal regulation, and not just object of legal relationship. The structure of legal relationship consists of objects, subjects and the content of legal relationship which dynamics is done by the legal facts. And other legal means are inherent in legal regulation of the relations: rules of law, right action, process of legal regulation, its mechanism, lawful behaviour and result of legal regulation [9, p. 127].

From this position M.Ya. Vashchyshyn econetwork is considered as subject to legal regulation in general and itdefines as an autonomous component of the All-European econetwork, the only interindustry and integrated subject to legal regulation has dynamic, complex and system character, consists of territorial structural elements, basic of which key territories (natural regions) within natural and reserved fund and also natural corridors, buffer zones and recovery territories, biologists and landscape variety and also improvement of conditions for formation and restoration of the environment, increase in natural and resource capacity of the territory of Ukraine are formed for the purpose of protection, preservation and restoration [9, p. 129].

O.O. Stativka considers econetwork as subject to ecology-legal regulation and in national econetwork suggests to 
understand the strategy of management and development of nature protection territories of Ukraine which promotes overcoming their fragmentation by integration into uniform territorial system, in indissoluble unity of its components of elements provides effective maintaining a biological and landscape diversity of species of wild flora and fauna, environments of dwelling (growth), increase in natural and resource potential, improvement of conditions for restoration of the environmental and also guarantees ecology-balanced development of the environment and makes a special part of the All-European ecological network [10, p. 140]. It is essential that in both approaches the national econetwork is allocated as an autonomous part of the All-European econetwork.

So, the econetwork is considered as multidimensional category:

1) embodiment of ecosystem approach in the course of, first of all, spatial and planning activity, also is basic institute of ecologically balanced development at the landscape and ecosystem level [4, p. 43];

2) organizational and functional basis of measures of preservation of a biodiversity in the conditions of anthropogenically transformed landscape [5, p. 28];

3) object of the ecological right which represents a certain complex of natural objects and their resources, but integrated at the wide specific level and the widespread territory of Ukraine [6, p. 95];

4) comprehensive natural and legal phenomenon which can help Ukraine to keep a valuable natural genepool, to use new effective control levers in management of environmental protection, will promote further ecological cooperation with the European Union [7, p. 94];
5) only interindustry and integrated subject to legal regulation, has dynamic, complex and system character, consists of territorial structural elements $[9, \mathrm{p}$. 129];

6) subject to ecology-legal regulation [10, p. 140];

7) strategy of management and development of nature protection territories of Ukraine [10, p. 140];

$8)$ territorial system.

The econetwork is a nature protection object to which the important task in the course of preservation and environmental protection is assigned and it is one of the most important prerequisites of sustainable development.

Especially it should be noted econetwork is important functional partof land of the country. However, it is not enough attention paid and the land aspect isn't revealed. However, as A.M. Miroshnichenko has noted, the earth is territorial basis for existence of natural resources, natural complexes itis the most important part of the surrounding environment [11, p. 18].

In the legislation it is put that the national econetwork will make $41 \%$ of all territory (lands) of the country. Its formation provides changes in structure of land fund of the country by reference (on the basis of justification of ecological safety and economic feasibility) parts of the lands of economic use to categories which are subject to special protection with reproduction of variety of natural landscapes.

Increase in acreage of the country with natural landscapes up to the level sufficient for maintaining their variety close to natural state and formation of their territorially uniform system constructed according to a possibility and natural ways of migration and distribution of species of plants and animals 
which provided preservation of natural ecosystems, types of a plant and animal life and their populations is planned (paragraph 1 subparagraph 3) [1].

So, we believe if to consider econetwork as subject to law regulation, then first of all as subject to ecology-land legal regulation. First, as it is already established, the econetwork is means of preservation and environmental protection in general. Its main function is nature protection which consists in ensuring ecological equilibrium, restoration and maintaining landscape and biological diversity, genetic fund, natural complexes and ecological systems. Secondly, a structural structure of econetwork are certain land plots which unite in the uniform territorial system of Ukraine. Formations of econetwork it is carried out by inclusion in the land plots and also the structure of land grounds (the woods, water objects, pastures, field-protecting and protective plantings, natural and reserved fund, etc.), to the data from the state land registry is based on information on category of lands: locations, total area, cadastral number and land plot, spatial coordinates (description of borders), about land owners and land users, etc., it is with observance of the land legislation.

The order of formation and existence of ecological network is regulated by the land and ecological legislation.

Providing definition to a concept of ecological network as subject to legal regulation it is impossible to ignore a basis of ecological network -land of Ukraine. Proceeding from it, the ecological network, first of all, it is a nature protection subject to ecology-land law regulation, unites in the uniform structured territory to the system of the earth which are a basis of a biological and landscape diversity, residences and growth of valuable species of an animal and flora, ways of migration of animals, for the purpose of creation of conditions for formation and restoration of the environment, preservation of natural complexes and ecological systems, increase in natural and resource capacity of the territory of Ukraine also is integral part of the All-European ecological network.

\section{Discussion.}

The developed ecological network will cover nearly a half of lands of the country. It is nature protection an object of ecology-land legal regulation, unites in the uniform structured territorial system of the earth which are a basis of a biological and landscape diversity, residences and growth of valuable species of an animal and flora, ways of migration of animals, for the purpose of creation of conditions for formation and restoration of the environment, preservation of natural complexes and ecological systems, increase in natural and resource capacity of the territory of Ukraine and it is integral part of the All-European ecological network.

In the article the considered questionsdemand further, more detailed research and introduction of the relevant proposals on improvement of the legislation according to modern requirements.

\section{References}

1. On approval of the Nation program of national ecological network formation for 2000-2015: Law of Ukraine of September 21, 2000 № 1989-III. Official bulletin of Ukraine (2000), 43, 5.

2. On ecological network of Ukraine: Law of Ukraine of June 24, 2004 № 1864-IV. Official bulletin of Ukraine (2004), 23, 53. 
3. All-European strategy of maintaining a biological and landscape diversity: International document on October 25, 1995. Available at: http://zakon.rada.gov.ua.

4. Movchan, Ya.I. (2011). Ukraina i ekokryza: shans chy apokalipsys? (mirkyvannia naturalista) [Ukraine and ecocrisis: chance or apocalypse? (naturalist's reasonings)]. Svitohliad, 34-44.

5. Kahalo, O.O. (2009). Rozbudova ecologichnoyi merezhi: pruntsypy, problemy, perspektyvy [Development of ecological network: principles, problems, prospects]. Lviv, 20-36.

6. Karakash, I.I. ed. (2012). Ekologichne parvo Ukrainy: pidrychnyk [Ecological law of Ukraine: educational book]. Odessa: Phoeniks, 788.

7. Lozo, A.V. (2014). Ekolohichna merezha yak pravovyi format rehuliuvannia ta okhorony landshaftiv [Ecological network as legal format of regulation and protection of landscapes]. Proceedings of Kharkiv National Pedagogical University named after H.S. Skovoroda, 21, 90-95.
8. Platonova, Ye.O. (2010). Pravove zabezpechennia formuvannia i funktsionuvannia ekolohichnoyi merezhi Ukrainy [Legal support of formation and functioning of ecological network of Ukraine]. Current problems of state and law, 173-178.

9. Vashchyshyn, M.Yu. (2014).Yurydychni oznaku ekologichnoyi merezhi yak obiekt pravovogo rehuliuvannia: Porivnialno-analitychne parvo [Law peculiarities of ecological network as subject to legal regulation: Comparative and analytical law]. 1, 127-129.

10. Stativka, O.O. (2017). Natsionalna ekolohichna merezha yak obiekt ekologo-pravovoho rehuliuvannia: teoretyko-pravove rozuminnia [National ecological network as subject to ecology-legal regulation: theoretically-legal understanding]. Legality problems, 136, 133-143.

11. Miroshnichenko, A.M. (2004). Koliziyi u pravovomy rehuliuvanni zemelnykh vidnosyn $v$ Ukraiini [Collisions in law regulation of land relations in Ukraine]. Kyiv, 206.

T.М. Кондратюк (2019). Поняття та ознаки екологічної мережі України. Доктринально-правові підходи до ії розуміння. Право. Людина. Довкілля, 10(1): 91-96, https://doi.org/10.31548/law2019.01.012.

Анотація. здійснено аналіз наукових підходів до визначення поняття "екологічної мережі» та ії ознак. Зроблена спроба визначити екологічну мережу як об'єкта екологоземельного правового регулювання.

Ключові слова: екологічна мережа, об'єкт правового регулювання, земельно-правова категорія, збереження природи 